\title{
Performance of a linear peristaltic infusion pump during red blood cells administration and the influence of infusion rates
}

\author{
DM Kusahara, M Pedreira*, AM Avelar, MA Peterlini \\ From ESICM LIVES 2015 \\ Berlin, Germany. 3-7 October 2015
}

\begin{abstract}
Introduction
Even with the technological development of infusion pumps, pediatric intensive care nurses are resistant to administer red blood cells (RBC) by linear peristaltic infusion pumps due to the supposed risk of cells damage, despite the need of accuracy in low flow rates. Patient safety can be compromised both by RBC quality decrease due to the pumping mechanism, as well as, by possible flow rate problems during the administration.
\end{abstract}

\section{Objectives}

To describe the level of hemolysis biomarkers and the hemolysis ratio of RBC administered by one linear peristaltic infusion pump. To verify the influence of three infusions rates programmed in a linear peristaltic infusion pump on the level of plasma hemoglobin and the hemolysis ratio.

\section{Methods}

An experimental study was accomplished with $3 \mathrm{RBC}$ bags (CPDA-1 preservative) from different donors with storage time ranging from 12 to 31 days. The linear peristaltic infusion pump was studied in triplicate. The equipment has a vertical peristaltic mechanism that compresses the administration tube halfway to closure and use a specific infusion set. The infusion pumps were set at $10 \mathrm{ml} / \mathrm{h}, 100 \mathrm{ml} / \mathrm{h}$ and $300 \mathrm{ml} / \mathrm{h}$. The hemolysis ratio (\%), plasma hemoglobin $(\mathrm{mg} / \mathrm{dl})$, potassium $(\mathrm{mmol} / \mathrm{L})$, lactate dehydrogenase $(\mathrm{U} / \mathrm{L})$, and haptoglobin $(\mathrm{g} / \mathrm{L})$ were analyzed. Samples for analysis were collected directly from the $\mathrm{RBC}(\mathrm{C} 1)$ bags external ports, after free flow of the blood component on the infusion disposable set (C2) and after submitted to the studied rate (E), exception

Federal University of São Paulo, Pediatric Nursing, São Paulo, Brazil made to haptoglobin that was analyzed in $\mathrm{C} 1$ and $\mathrm{E}$. Data obtained were analyzed according to mean \pm standard deviation, ANOVA and $\mathrm{t}$ student tests $(\mathrm{p} \leq 0.05)$.

\section{Results}

A total of 54 analyses were performed. The comparisons between $\mathrm{C} 1, \mathrm{C} 2$ and $\mathrm{E}$ biomarkers values and hemolysis ratio demonstrated no significant variation: plasma hemoglobin of $0.92 \pm 0.22,0.90 \pm 0.21$ and $0.94 \pm 0.20$ $(\mathrm{p}=0.966)$; potassium $30.0 \pm 2.6,30.5 \pm 2.6,30.8 \pm 3.8$ $(\mathrm{p}=0.459) ;$ lactate dehydrogenase $705.2 \pm 207.4$, $739.9 \pm 239.6$ and $778.3 \pm 318.7(\mathrm{p}=0.475)$; hemolysis ratio $0.136 \pm 0.038,0.127 \pm 0.035,0.136 \pm 0.049(\mathrm{p}=$ $0.615)$. The haptoglobin level was statistically similar between $\mathrm{C} 1$ and $\mathrm{E}(70.2 \pm 38.1 ; 70.2 \pm 38.0 ; \mathrm{p}=0.993)$. Comparisons of the studied infusion rates evidence significant variations $(\mathrm{p} \leq 0.001)$ in plasma hemoglobin levels among $10 \mathrm{ml} / \mathrm{h}(0.106 \pm 0.013)$ and $300 \mathrm{ml} / \mathrm{h}$ $(0.072 \pm 0.018)$, and comparing $100 \mathrm{ml} / \mathrm{h}(0.098 \pm$ $0.010)$ and $300 \mathrm{ml} / \mathrm{h}(\mathrm{p}=0.002)$, without variations $(\mathrm{p}=$ 0.164 ) between $10 \mathrm{ml} / \mathrm{h}$ and $100 \mathrm{ml} / \mathrm{h}$. The infusion rate did not influenced significantly the hemolysis ratio $(\mathrm{p}>$ 0.05 ), that was $0.145 \pm 0.030$ at $10 \mathrm{ml} / \mathrm{h}, 0.131 \pm 0.032$ at $100 \mathrm{ml} / \mathrm{h}$, and $0.122 \pm 0.053$ at $300 \mathrm{ml} / \mathrm{h}$.

\section{Conclusions}

The overall analyzes of the studied biomarkers and hemolysis ratio of $\mathrm{RBC}$ demonstrated no significant alterations related to the peristaltic infusion pumps, and the infusion rate of $300 \mathrm{ml} / \mathrm{h}$ caused less variation on plasma hemoglobin than $10 \mathrm{ml} / \mathrm{h}$ and $100 \mathrm{ml} / \mathrm{h}$.

\section{Grant Acknowledgment}

FAPESP-Sao Paulo Research Foundation n.12/25284-9. 


\section{Submit your manuscript to a SpringerOpen ${ }^{\mathcal{O}}$ journal and benefit from:}

- Convenient online submission

- Rigorous peer review

- Immediate publication on acceptance

- Open access: articles freely available online

- High visibility within the field

- Retaining the copyright to your article

Submit your next manuscript at $\gg$ springeropen.com 